\title{
"A Collection of Stories, Poetry and Theories": Homelessness, Outsider Memoirs, and the Right to Theorize
}

Jessie Speer, Queen Mary University of London

\begin{abstract}
This paper argues that memoirs of homelessness advance a form of social theory that emerges from the lived experience of homelessness and housing displacement. While scholars have called for greater recognition of previously neglected forms of social theory, academic scholarship remains - in practiceoverwhelmingly influenced by the theories of a narrow group of high-profile intellectuals and specialist textual forms. Life narratives, in particular, have often been framed as atheoretical testimonies, and homeless thinkers have been largely denied the right to theorize. This paper argues that reading "outsider memoirs" as theoretical texts can be a method for expanding current understandings of the nature of social theory and taking seriously the epistemic rights of marginalized thinkers. It engages with the writings of homeless memoirists to argue for a new understanding of the explanatory power of social theory that does not collapse into abstraction or generalization, but is profoundly rooted in reflection and collaboration. Key Words: homelessness, memoir, narrative, theory, knowledge.
\end{abstract}

So much about the experience of homelessness and abject poverty is humiliation. ... Your awareness and knowledge are not considered scholarship, your words are not valued as art or theory.

- Lisa Gray-Garcia, Criminal of Poverty

\section{Introduction}

Years ago, I traveled to California to research the development of large-scale homeless encampments in the dusty agricultural city of Fresno. In speaking with people who lived in the camps, interviews morphed into conversations, and conversations into testimonies. Participants not only shared memories and stories, but also critiqued local politics and imagined alternative social practices. Yet I was ill-equipped to account for the richness and depth of these interviews in my academic writing. Instead, the profound insights of people I 
spoke with often became empirical data to support the theories of vaulted, distant, and elite intellectuals.

Frustrated by this lopsided attribution of knowledge, I determined to cite those who experience homelessness as theorists in their own right, whose ideas about society and space have far-reaching implications and powerful explanatory logics. In searching for source material, I was drawn into the burgeoning genre of life narrative, as homeless speakers and writers increasingly represent themselves to the public in their autobiographies and oral histories. ${ }^{1}$ Through the shift from traditional social scientific interviews towards life narrative, I came to a deeper understanding of the nature of social theory.

Feminist scholars have long acknowledged that theory is not a heady, abstract project limited to a narrow group of intellectuals, but a practice that people engage in throughout their daily lives. At the same time, little feminist work has examined what - if not abstract explanation — distinguishes theory from other forms of thought and speech. If all text becomes theory, the notion of theory begins to lose its conceptual value. In my aim to interpret the theories of homeless and formerly homeless memoirists, I was faced with interrogating this elusive category of knowledge. In the section that follows, I turn to academic literature on social theory, knowledge production, and autobiography to argue that life narratives can reveal a deeply relational and intimate kind of theory in which knowledge speaks beyond a singular context through connection across difference, rather than abstraction or erasure. I then examine how homeless and formerly homeless writers advance this profoundly relational theory-building in the form of "outsider memoirs." While memoirs of homelessness have been overwhelmingly overlooked in academic scholarship, attention to such texts reveals a kind of collaborative and reflexive theorizing that opens new lines of inquiry into the problems and possibilities of contemporary housing and domesticity.

\section{Reading Memoir as Theory}

A narrow canon of theoretical literature has been enormously influential in shaping Anglophone conversations in the social sciences and humanities today, as well as the development of disciplinary divisions within academia. This canon of social theory-including the writings of Karl Marx, Emile Durkheim,

\footnotetext{
${ }^{1}$ As oral history constitutes a distinct form with its own strengths and limitations - and archives of oral histories of homelessness are complex and unique sites of knowledge production-I discuss my research of homeless oral history archives in depth elsewhere (Speer 2018) and focus here on memoirs of homelessness.
} 
and Michel Foucault, for example - began to emerge in nineteenth century Europe as a new, mixed genre combining literature, history, philosophy, and economics to advance ideas that could speak to a wide range of social contexts (Culler 2011). Yet by and large, the theoretical canon was restricted to a narrow group of thinkers whose uniquely situated interests and perspectives were framed as universal knowledge. In particular, the historical process of canon formation privileged European, elite, and masculine social perspectives, while excluding and subordinating other kinds of knowledge (Connell 1997, 2007). In the 1970s and 1980s, a growing body of feminist, postcolonial, queer, and critical race theories began to critique such totalizing narratives, and by the mid-1990s, the project of theorizing itself was subject to widespread scrutiny (Elliott and Attridge 2011). Many scholars - particularly in the field of literary criticism - pronounced the end of theory as an intellectual project (Payne and Schad 2003). Today, social theory is often regarded as an outmoded process through which "oracular figures" shape intellectual debates across multiple disciplines (Elliott and Attridge 2011, 3).

At the same time, the need to theorize contemporary political and social life remains as pressing as ever, as global inequality continues to rise (Eagleton 2004). As the theoretical canon historically denied women, minorities, and working classes access to "the universal"-and instead tokenized such groups as speaking only on behalf of a particular, limited situation - it is crucial to expand the canon of social theory rather than doing away with it altogether. In this vein, Avery Gordon (2008, xviii) argues for the "right to theorize," as a right "to be something other than a local knowledge governed or interpreted by a putative superior." The right to theorize can thus be understood as a right to be included in the canon of influential literature and interpreted as theoretically useful. While Jack Halberstam (2011) argues that any text can be interpreted as theoretical, it remains unclear what such a reading entails in practice. Rather than simply abandoning theory - or expanding it to include everything - it is necessary to examine critically what distinguishes theory from other forms of knowledge. This is not to police the boundaries of thought, but to retain the conceptual usefulness of a powerful category of knowledge in order to include thinkers who were previously deemed atheoretical.

While theory has been framed as a form of storytelling (Nagar 2013), it also holds the power to influence how other stories are told. If social science observation involves selecting what facts to include and how to present themin short, creating a story - theory involves the bolder assertion of a "master narrative" according to which other stories are interpreted (Gorelick 2011; Riessman 1993). Theories are controversial in their very nature, as theorybuilding is a speculative, uncertain process that seeks to answer nagging and 
unresolved questions through open debate (Culler 2011). In this way, theory has the power to shape future conversations. Yet today in the social sciences and humanities in particular, theoretical literature is often divorced from concrete struggles and practices, suggesting that everyday language is uncritical and naïve (Nagar 2014). To overcome this is not to valorize popular common sense, but to recognize that the supposed chasm between everyday thought and theory is itself constructed. As Rita Felski $(2015,181)$ argues, the antidote to the dangers of universalizing narratives is not "a repudiation of theory ... but an ampler and more diverse range of theoretical vocabularies."

In the search for a greater diversity of theoretical forms, autobiography presents a powerful resource through which to engage in concrete, evocative modes of theorizing that connect social phenomena to the scale of everyday, lived experience. While the genre was historically leveraged as a tool for powerful men to affirm their place in history, it was also a platform from which marginalized groups could launch social critique (Purcell 2009). As Raymond Williams (1989) writes, English working-class writers for many generations produced literary forms centered on the "I" narrator. In the post-colonial context, marginalized groups often used personal testimonies as forums for political dissent (Beverly 1993; Poitevin 2002). Such work led to the development of an "outlaw genre" of autobiography (Watson and Smith 2001). In the United States over the past several decades, memoirs have risen in prominence to become a dominant literary form. The memoir boom in the contemporary era - in which the number of new autobiographies tripled between the 1940s and 1990s - opened the genre to include an even wider range of unofficial histories (Gilmore 2001). Through this growth, new forms of knowledge have developed with the power to reveal "what more conventional autobiographies obscure" (Gilmore 2001, 137). Such nontraditional autobiographic forms can be understood collectively as "outsider memoirs," a term I discuss in more detail in the section following this one.

Alongside the memoir boom, analysis of autobiography has grown as a methodology in the social sciences. Geographers have increasingly analyzed memoir to examine the relationship between memory, narrative, and place (Hawkins et al. 2016; Moss 2001; Purcell 2009). Such work acknowledges that autobiography is not only literary, but also reflects on personal values, norms, identities, logics, and conclusions, as well as critical analysis of society (Walker 2017). Autoethnography has developed into a rich genre of its own, broadly defined as the study of the self in relation to society, and often used as a tool to shed light on how researchers' social positions impact their conclusions (Butz 2010; Butz and Besio 2009). Feminist scholars have also turned to "collective biography" as a method that engages in collective life 
writing and interpretation to move beyond individualistic forms of memoir and work towards identifying larger structural understandings about the relationship between individuals and society (Hawkins et al. 2016).

In many ways, autobiography is not limited to, or indeed centered on, a discussion of the self. Beyond drawing a sketch of the self, autobiography depicts the context in which a life is lived. As with autoethnography, it can be read as a narrative about the world that is explicitly subjective and experiential. In the case of outsider memoirs, autobiography can be seen as an outward looking observation of a world from which one is excluded or displaced. Indeed, a growing body of autobiographic writing by disenfranchised groups actively subverts the traditional rules of the genre, interweaving both social commentary and self-reflection. For Lia Nicole Brozgal (2013), to read a text solely as a story of about an individual author is to limit its analytical possibilities, as with French philosophers who interpreted the works of many North African thinkers as narrowly autobiographical, thus limiting their theoretical reach. Brozgal $(2013,56)$ writes that such postcolonial literature was effectively assigned to what Tahar Ben Jelloun called the "ghetto of autobiography." Instead, she argues, autobiographical texts can be conceived of as employing a complex, varied theoretical discourse in their own right. To read such texts as theory, she writes, "is to unsettle our received notions of what theory is and where it may be found" (Brozgal 2013, xiv).

Memoir can be also seen as advancing an emotional mode of theorizing. While the task of connecting disparate phenomena has often been left to abstraction, the emotional power of storytelling can also draw connections across different experiences, and between individual and collective realities (Narayan and George 2002). As Bondi (2005) argues, emotion is not simply an individual experience but is a social phenomenon that exists in relationships between people. In contrast to abstraction, memoir in particular can help readers experience an emotional kind of knowing that is both deeply social and personal. Placing life narratives alongside each other further enables an understanding of shared vulnerability across widely different circumstances. Ruth Behar (1996) argues that writing about the self is a kind of "vulnerable writing" through which to connect across difference and challenge the boundaries of social scientific observation. A personal voice, rather than shrinking the object of analysis, can open the conversation to reveal connections between intimate and social phenomenon.

In addition to emotional theory, memoir enables a kind of theory that is deeply grounded in the realm of concrete experience. Across multiple forms, memoirists draw from their own experiences as their primary source material 
and make an implicit promise to recount their experiences truthfully. Yet memoir has been subject to critique for promoting experience as a basis of knowledge (see Stanley 2012). Indeed, the truth-telling pact of memoir is often broken, as with autobiographies found to be fraudulent (Watson and Smith 2010). More broadly, experience cannot be treated as innocent or transparent, as it is filtered by language and often reinforces problematic ideologies and understandings of identity (Harding 2016; Scott 1991). For outsider memoir in particular, the experience of oppression does not necessarily afford a more critical worldview, and the notion of a "pure" oppressed consciousness risks reinforcing essentializing tropes (Butz 2010; Haraway 1988). Yet while memoirs cannot be read as straightforward accounts of historical truth, reflexive stories nonetheless offer crucial theoretical insights that emerge from personal experience, and can be read as theoretical reflections on memory.

Indeed, reading memoir as a theoretical text enables a critical stance towards autobiographic claims, while also taking seriously the theoretical contributions of marginalized thinkers. Theory, in its nature, is a kind of knowledge designed for debate, conversation, translation, and critique. It is a fluid and interpretive process, constantly remade through connection and partiality, as each subjective insight offers one piece to a larger tapestry of truth (Collins 2002). Memoirs, read as theory, can thus be assessed, critiqued, and built upon by placing them in a broader intellectual conversation. Such analysis can remain sensitive to the dangers of romanticizing or appropriating oppressed consciousness, while also acknowledging that the project of theorizing must be expanded to include previously displaced voices. In this way, accounts of marginalized experiences can be recovered not as a form of naïve empiricismnot to arrive at a "truer" version of reality - but as one part of a larger conversation about history and society (Moya 2002; Stone-Mediatore 2016).

Critics of autobiography have also argued that it promotes a simplistic notion of the self, based in bourgeoisie humanism, when "selfhood" should instead be understood as fragmented, multiple, and shifting. Yet autobiography can capture the complex, fluid, nature of the ordinary self (Stanley 2012). Centering the knowing subject does not naturalize the subject; instead, it allows for complexity and honesty about the limits of knowledge. Another strand of criticism insists that the specificity of the author is unimportant, as authors are themselves the product of larger social discourses. Yet Brozgal (2013) argues that it does matter who is writing, as certain groups are denied authorship altogether, an erasure with profound impacts on the nature of discourse itself. Too often, disenfranchised groups are referred to as part of an anonymous and uniform collective rather than as a diversity of thinkers, each with rich and complex lives (Brozgal 2013). Autobiographic reflection enables a more 
transparent form of authorship, in which claims are explicitly grounded in the particular location of writers' lives. Liz Stanley $(1993,1995)$ argues that autobiography can challenge the divisions between individual and society, self and other, and reveal how knowledge is constructed, rather than discovered.

Altogether, autobiography resists the depersonalized aspirations of theory, while also reaching beyond place and time to shed light on broader social realities. It reveals how abstraction is linked to intimate worlds, and conversely how memory is laden with theoretical implications. Memoirs in particular capture how intellectual inquiry is both rooted in the personal life of the intellectual, at the same time as it represents something beyond the self. When narrators reach beyond themselves to connect with an audience - and their story resonates with others - they move beyond narrow factual accounts into emotional modes of theory building. Systemic critique and generalization can emerge through ongoing and open dialogue, without flattening differences between unique experiences. As I argue in the section below, memoirs of homelessness often engage in this kind of reflexive project, drawing connections between and across locations, with the broader aim of disrupting easy doctrines and ultimately challenging the structural problems of housing inequality and displacement.

\section{Homelessness, Outsider Memoir, and the Right to Theorize}

Alongside the decentering of canonical social theory, contemporary academic scholarship on poverty and homelessness must also be historicized as a specific form of knowledge. For the most part, memory and narrative have largely been overlooked in such literature, in favor of medicalized approaches to illness and addiction (Blasi 1994; Buck, Toro, and Ramos 2004). In seeking to frame homelessness as a solvable problem distinct from systemic inequality, such work often aims to change homeless people, rather than challenging housing markets or domestic norms. When life histories are included in journalistic and academic accounts, such stories often preclude homeless people from discussing the politics of homelessness itself, and are used instead to garner sympathy for shelters and service centers (Renedo and Jovchelovitch 2007). Indeed, quotes from homeless people in such literature overwhelmingly focus on individual stories of failure and redemption rather than the general reality of homelessness (Schneider 2012). Such stories tend to frame "the homeless" as passive beneficiaries of assistance, and diminish life narratives to discrete pathways analyzed as tools for therapeutic intervention. Such methods tend to obscure the rich complexity of biography behind a series of labels (Hodgetts, Cullen, and Radley 2005; Somerville 2013). As Barbara Schneider (2012) 
argues, homeless people are rarely given opportunity to engage in abstract critique. In being prevented from defining homelessness, critiquing housed society, or imagining alternatives to expert solutions, homeless people are denied the right to theorize.

At the same time, a growing range of scholarship seeks to move beyond the hierarchies of expertise embedded in academic research on poverty (Elwood, Lawson, and Sheppard 2017; von Benzon and van Blerk 2017). Research on homelessness has increasingly turned towards auto-photographic methods - in which homeless participants use cameras to document their everyday lives - to more accurately reflect the spatial perspectives of people of who experience homelessness themselves (Johnsen, May, and Cloke 2008; Schmidt and Robaina 2017). May (2000) argues that biographic interviews can enable scholars to move beyond the reductive category of the homeless "other" and challenge individualized explanations of homelessness. Yet fieldwork-based research requires a narrow object of analysis, and cannot capture a wide spectrum of social experience across distinct social contexts. On the whole, studies of homelessness overwhelmingly engage in an either/or approach to personal and political questions (Renedo and Jovchelovitch 2007). As Gary Blasi $(1994,582)$ argues, studies of homelessness "lack a coherent set of methods for bridging the gap between the micro/individual and the macro/structural." Memoirs thus present a crucial source through which to examine homelessness as both an intimate and structural phenomenon, and to understand lived experience across multiple contexts.

Scholars engaged in participatory work with vulnerable groups are also seeking new ways to account for the profoundly emotional experience of doing such work (Askins 2009). A growing body of methodologically experimental geographic research has turned towards fiction and poetry as tools through which to elucidate the full impact of emotional knowledge and challenge positivist claims to universality (Eshun and Madge 2012; Rabbiosi and Vanolo 2017). Research on homelessness has recently turned towards ethnographically informed storytelling and novel-writing as emotionally-urgent modes of dissemination that have the potential to impact communities who are the subject of the research (Christensen 2012; Lancione 2017). While my own research was removed from the intensity of the ethnographic moment, the practice of reading hundreds of life narratives of homelessness left me deeply sensitive to the vulnerability of the human condition, the profound lack of social care in the United States today, and the epic quality of each human life. It also prompted me to engage in my own life-writing, a practice which was integral to the larger research project (see Speer 2018). 
Currently, digital repositories and public libraries contain more than 215 contemporary, English-language, U.S.-based memoirs of homelessness. To identify this list of memoirs, I consulted multiple library and bookseller databases. For the sake of specificity, I limited my search to authors who describe themselves as having experienced homelessness, and to memoirs written over the past three decades. While the word "homeless" by its very nature excludes those do not self-identify as homeless, no word in the English language encompasses all those who have been displaced from their homes. Thus, the collection I identify here is far from complete. Nonetheless, it is a starting point from which to analyze the genre, and understand how it can contribute to the wider conversation on housing and homelessness. Many authors describe living on the streets or in shelters at the time of writing, and a large minority attest to experiences of childhood homelessness. Roughly one third of the authors are women, and roughly the same percentage are writers of color. Nearly half of the memoirs are set in only eight cities-New York, Los Angeles, Washington, D.C., San Francisco, Chicago, Houston, and Boston.

Memoirs of homelessness are often overlooked as part of the broader literary canon. While Lee Stringer's memoir Grand Central Winter was translated into eighteen languages - including Chinese, Japanese, Norwegian and Dutchonly about a dozen out of 215 memoirs were republished in English, translated, or otherwise widely disseminated. According to a search of multiple library databases, more than half of all memoirs of homelessness are unavailable in the U.S. library system, and many are accessible only as digital files, or "eBooks." This trend reflects a self-publishing boom in the last two decades, as three times as many memoirs of homelessness were published after 2010 than before, with 68 percent of these being self-published. Thus, the astronomical growth of the genre must be examined alongside both the rise of memoir as a literary form, as well as the availability of free digital publishing platforms.

Digitization has revolutionized the way in which publishing industries historically limited authorship to a select few. As open source publisher Richard Nash argues, "It's a model where anyone can create, as it was before the Industrial Revolution. Anyone could create a song, tell a story" (Rossetti 2015). Yet despite the dramatic democratization of the publishing industry, digital memoirs of homelessness remain absent from the mainstream physical repositories of textuality: libraries and bookstores. Further, many homeless authors engaged print publishers notorious for their exploitative practices, including Tate Publishing and PublishAmerica, both of which were involved in multiple scandals for overcharging authors and providing inadequate services (Byle 2017; Zeitchik 2004). 
By and large, journalists and social scientists have not analysed memoirs of homelessness. Lars Eighner $(2013,291)$, who wrote Travels with Lizbeth, perhaps one of the most well-known memoirs of homelessness, describes his own book as an outsider memoir, suggesting that it belongs to a genre defined by its outsider status. For those who write about the experience of homelessness, memoirs attest to the experience of living both literally and metaphorically outside of market housing and housed society. As Eighner writes, his memoir was often subject to suspicion simply because of his homelessness. He describes "a number of odd questions, winks, and nudges I received when I was interviewed or questioned less formally about my book. Apparently many literary people suspect that an outsider memoir is not entirely on the up-and-up" (Eighner 2013, 291). To read and cite memoirs of homelessness as theoretical sources is to push against notions that homeless people can only testify to their own idiosyncratic experience, or that one cannot generalize from an outsider position.

Many memoirists highlight the importance of theorizing from the experience of homelessness. Lee Stringer began writing his memoir, Grand Central Winter, while living underneath Grand Central Station in New York City. He wrote an advice column for New York City's "street newspaper" about the reality of being homeless. He quotes one column at length in his memoir, recounting how he responded to a question about his "credentials."

I have no qualifications ... except for the fact that for the last eight years I have lived with less inconvenience than you might imagine on the streets of this city.... The fact that I do not have a degree on my wall does not imply any opposition on my part toward higher education. Perhaps readers could benefit from a more lettered author. ... Of course I might lose my authority as a bona fide street person. $(1998,181)$

Using humor, Stringer destabilizes the idea that a college degree is the only legitimate form of of "qualification." He compares the personal experience of homelessness to a university education, and identifies his lived material reality as lending him authority on the subject of homelessness.

Other writers framed their homelessness as a source of expertise on the subject of housing inequality. John Sibley wrote his self-published memoir Being and Homelessness while living in parks and shelters on the south side of Chicago. He argues that homelessness sharpened his critique of structural inequality, writing: "Once you are stripped of your dignity and humanity - even your right to exist-your sense of being-in-the-world changes. Your cultural lenses become sharper, more critical. You start to focus on the greed, racism and 
corporate swindles caused by homo economicus" (Sibley 2011, 31). In drawing upon the philosophical concept of "being-in-the-world," Sibley suggests that a person's very being is inseparable from the conditions in which she dwells.

Thus, the intolerable condition of homelessness creates a new and fundamentally critical outlook on the world.

For Eighner, homelessness is a source of knowledge about social service systems and coping strategies for adapting to conditions of extreme hardship. He writes, "I thought it a shame to be well situated to learn of other homeless people and to neglect to try to do so. Besides being intellectually curious, I thought I might acquire some practical skills." He continues, "I had discovered I could learn nothing of value from social workers. Social workers, after all, never try to use the systems they establish and operate" $(2013,202)$. Thus, for Eighner, the experience of using social services affords people a unique vantage from which to understand the functioning of service systems themselves. Commenting on writers who "masqueraded" as homeless in order to conduct research, he states, "whether those writers thought of themselves as journalists or participant observers, or something else, they certainly had the right approach for learning something about homeless people" $(2013,289)$.

Lisa Gray-Garcia, in her memoir Criminal of Poverty chronicles her lifelong project of promoting homeless people's scholarship. She writes about the first time she published an article in a local newspaper:

There it was in print, my name, my struggle to survive, my solutions, and my words. ... For folks dealing with extreme poverty, recognition can be a lifeline with life-changing implications. So much about the experience of homelessness and abject poverty is humiliation. ... Your awareness and knowledge are not considered scholarship, your words are not valued as art or theory, you are talked about, not spoken with, written about, not read. (2006, 183-184)

Gray-Garcia attributes her survival, in part, to the experience of finally being heard. She argues that homeless people's knowledge must be read not only as story and memory, but must also be valued as theory. She thus seeks to subvert the hierarchy according to which only certain texts are awarded the label of theory. In this way, as Stringer, Sibley, Eighner, and Gray-Garcia argue, those who have been displaced from housing should be read as having a degree of intellectual authority on the subjects of homelessness, poverty, housing, and social service infrastructures. 
Inspired by her first publication, Gray-Garcia and her mother developed a collective of "poverty scholars," many of whom were homeless, under the umbrella of POOR Magazine, a publication written by and for homeless and poor people. As Jessica Hoffmann (2013) writes, in their aim to "center the voices and stories of often marginalized people, POOR has innovated numerous models of "horizontal media production." Gray-Garcia explains her inspiration for the project: "I knew that everyone who wanted to write, who wanted to make art, who wanted to be heard but who didn't have the access to education, time and/or resources, should be given that space, that ability, that voice" $(2006,212)$. She highlights the importance of having a venue-of everyone being "given that space"-through which to make their experiential insights heard. She writes:

In the first year of our organization, we developed the notion of poverty scholarship, which was inducted into POOR's core practices with the clear realization that poor folk had to flip the power of media, voice, and authorship. Poor people are inherently denied a voice in the media, and they're also denied a voice in the creation of legislation and academic scholarship. Consequently it became POOR's goal to intentionally listen, to conceive of policy and reassign authorship to the folks on the frontline of the experience of poverty and racism. (2006, 229)

Since the first issue of POOR Magazine was published in 1996, the organization has expanded to include an online magazine, a twice-monthly radio broadcast, video reporting, and an oral history collection (Hoffmann 2013). In this way, POOR actively subverts the notion that scholarship is only the purview of elite institutions.

In addition to their theoretical richness, memoirs of homelessness are also profound testimonies to the experience of being displaced from housing. As with non-traditional memoirs that subvert the binary between theory and testimony, many homeless writers transition continually between storytelling and theorizing. As Eliana Chaya writes about her self-published eBook Fashion Tips for the Homeless Woman (2014):

My book is described as a collection of stories, poetry and theories.... I understand I broke a rule (not the first or last time I will do something unconventional) by combining a sort of memoir form with education and theories.... I will not change the format, which was planned very much on purpose. (Chaya 2015) 
Many other narrators interspersed prose and poetry with stories and ideas. In her memoir of domestic violence and homelessness, Stephanie Rodriguez reveals her transition from story to theory. She writes, "I've told this story in small pieces .... In the process, I have found, I think, a larger truth. My husband didn't do what he did to me by himself. He had plenty of help. His parents, my parents, our society all worked together" (1994, p. 9). In forming a supposition about society at large, Rodriguez stakes a claim in the unequal terrain of ideas. Her search for a "larger truth" is also a claim to ideological authority, and the power to influence knowledge. In this way, she uses her own story to assert a socially meaningful idea, rather than a mundane or prosaic account only useful to support other ideas.

Memoirs of homelessness also challenge the notion of the author as an autonomous individual. Anika and Sakeenah Francis (2013) published Love's all that Makes Sense: A Mother Daughter Memoir as a series of letters to each other describing their memories of homelessness and mental illness. Lisa GrayGarcia $(2006,181)$ also included her mother as a co-author in her early writings. She writes about her decision:

I had decided to give co-authorship credit to my mother, believing that even though it was me writing the essay, it was her life as well as mine, her struggle as well as mine and her tenacity even more than mine that informed the writing. She deserved to be recognized along with me. With that essay and countless more later on, I always gave her credit, along with the other poverty scholars to follow. $(2006,184)$

In addition to co-authorship, many homeless memoirists describe their life story as encompassing the stories of others. As Chris Gardner $(2006,11)$ writes in his now-famous memoir The Pursuit of Happyness, referring to his mother, "my story is hers." In their focus on co-authorship, memoirs of homelessness challenge notions of the solitary thinker who breaks through into new areas of thought. As with anti-colonial testimonios, many memoirs of homelessness are transcribed from oral testimonies by an intermediary who is sometimes listed as co-author. In her memoir, Gray-Garcia discusses her own efforts to promote the writing of homeless authors, using testimony as a methodology. She writes that those interested in contributing to POOR Magazine who were unable to write "were assigned a writer/facilitator who would listen and transcribe their stories, struggles and concepts into a piece of prose or journalism" (2006, 229). She emphasizes that those who spoke their stories should retain authorship of the written product: "if you have lived through an experience and are, therefore, the subject of a story, you should get authorial credit. ... It was a collective, nonindividualistic way of thinking and acting" $(2006,229)$. In this way, Gray- 
Garcia sought to work towards equity between homeless scholars and writers with greater educational or linguistic privilege.

As with the broader genre of autobiography, outsider memoirs cannot be read as straightforward empirical accounts. John Allen (2004) argues that the memoir My Life on the Street by Joe Homeless (1992) recounts violence and hostility so extreme that it lacks credibility. Indeed, recalling memories accurately is particularly challenging for those who experience the constant displacement that is associated with homelessness. As Nathan Monk (2015, chapter 4) writes in his self-published eBook Chasing the Mouse, "I've attempted to accurately chronicle the timeline of events between houses and motels to no avail. I have estimated that we lived in some forty different locations, maybe more ... . I will not try to force this madness into a neat chronological series of events. It would be nearly impossible." Many memoirs of homelessness are also written from the perspective of housed comfort, and recall homelessness as a distant memory. For such formerly homeless writers, memory can become distorted by judgmental distance and can reinforce tropes about the "recovered" homeless person who has "battled the odds" to overcome the personal failure (see Hodgetts, Cullen, and Radley 2005, 33). While memoirs of homelessness are not simply straightforward factual accounts, they can nonetheless be read as theoretical reflections on the relationship between society and the self, and more specifically between housed society and the experience of homelessness.

This is not to suggest that memoirs of homelessness should be read uncritically. Indeed, many who experience homelessness internalize hegemonic discourses of self-blame, and frame their own homelessness as deviance and failure to conform (Lyon-Callo 1999; Purser 2016). Many memoirs and oral histories of homelessness similarly reiterate predominant representations of homelessness or aspire to conservative visions of domesticity. Thus, homelessness cannot be seen as a "pure" location on which to ground an oppositional knowledge. To frame homeless memoirists as having a clearer vision of oppression risks not only perpetuating a romanticized stereotype, but fetishizing "the homeless" as an already-constructed object of elite knowledge. Yet while homelessness does not always afford an oppositional worldview, many homeless memoirists engage in work of building critical social theory. As Teresa Gowan (2010) argues, those who experience homelessness do not only espouse "sin" and "sick" talk-attributing their homelessness to moral failures or pathologiesbut also engage in "system talk" that directly critiques the structural dynamics of inequality. In theorizing about their conditions, many memoirists challenge the social systems to which they are subject. Rather than critiquing the ways in which memoirs of homelessness reproduce problematic discourses, or 
conducting a straightforward social-scientific analysis of their content, it is useful to build upon their critical insights that shed new light on social problems.

In addition to critiquing society, many memoirs of homelessness engage in the practice of self-reflection. Gray-Garcia writes about the efforts of POOR Magazine, in promoting poverty scholarship, to foreground self-reflexivity through life writing. She writes, "POOR's rule from the beginning was to break down the myth of objectivity and the implicit 'other' stance of journalism. We accomplished this through the integration of self, the use of ' $\mathrm{I}$ ' in every story; no Dickensian positivism here. We were the subjects" $(2006,230)$. In the writers' workshop Gray-Garcia co-organized, participants "were encouraged to write about their truths from a first-person perspective. ... [This] required folks to be honest about their personal positions of oppression" $(2006,212)$. GrayGarcia suggests that writing about the self can be a method for honest reflection that challenges the idea of a singular, universal truth.

Other life narrators similarly promote the project of self-reflection, and advocate a critical stance toward all knowledge claims. As Eighner writes:

I must reveal some attitudes of which I am not proud. I have racist and sexist ideas and other faulty ways of thinking which do not have convenient names. I report these frankly. Not because I think my prejudices are correct, but because ... I think sunlight and fresh air the best treatment of an abscess. I have great faith in the truth. And as a member of an oppressed minority, I know I would rather confront the true opinions of my adversaries. ... Admitting to occasional doubt, I think, is a sign of strength, not of weakness. In any event, so I suppose, doubt has never done harm while unshakable certitude has caused unspeakable suffering. (1991, 5-6)

In uncovering these "faulty ways of thinking," Eighner asserts that his knowledge is limited by his own biases, and that honesty and the admission of self-doubt are "the best treatment" for overcoming these biases. Stringer also takes a critical stance toward truth claims and advocates a "practice of doubt" (1998, 100). He writes:

It's relatively easy, when writing editorials, to pick a target and start firing away. Or to stand firmly on one side of a hot issue or topic and spout off. But nothing in this imperfect world is beyond dispute. I'm not saying there is no need for a sense of right and wrong. There is. But people's lives proceed under an infinite variety of circumstances. And I find it perilous to pass judgment. ... Beneath the 'right' and 'wrong' of 
issues and the 'pro' and 'con' of our positions, however, lies the vital matter of our relationship to the events behind them. (1998, 190-191)

In writing that ideological positions emerge from one's "relationship" to the underlying events, Stringer suggests that all knowledge is subject to critical examination of whose interests it promotes. Altogether, these insights reveal that memoir not only presents the possibility for a radical right to theory, but can advance a more complex, collaborative, and reflexive form of theorybuilding.

\section{Conclusion}

As with the larger genre of autobiography, memoirs of homeless do not fit neatly into any single textual category, as they often blend political thought with personal reflection. Many homeless narrators describe their experiences and memories, engage in critical reflection, and imagine possible futures. At the same time, many narrators engage in work of building critical social theory by disputing common sense notions, being skeptical towards easy doctrines, and engaging in self-critique and reflection. This burgeoning literary genre of homeless people's life writing - marked by its marginalization, rhetorical flexibility, and co-authorship - provides a framework for bridging the mico/macro divide in theorizations of homelessness. Further, memoirs of homelessness not only engage in critical analysis, but also envision alternative models of place that challenge the violence of housed society. They are not simply chronicles of trauma but are also rich with aspiration and imagined futures.

Altogether, memoirs of homelessness move beyond current understandings of the nature of theory. In blurring the lines between theory and narrative, abstraction and intimacy, critique and imagination, they reveal that theory cannot be read only according to partitioned methods of social scientific or literary inquiry. While feminist scholars have long engaged in critical debate on the nature of knowledge production, academic scholarship often implicitly relies on taken-for-granted notions of what theory looks like and where it can be found. Many who seek to expand existing theoretical vocabularies-beyond the writings of high-profile academic intellectuals - often inadvertently reinforce the primacy of a narrow group of feminist scholars, many of whom I cite here. Poverty scholarship - and outsider memoir in particular-flips this tendency by framing homeless writers as experts and theorists to be consulted in the project of building knowledge. Outsider memoir further calls for a fundamental right to theorize, not simply as an academic exercise, but as a struggle against ideological exclusion in all of its manifestations. The right to 
theorize does not only intervene in the realm of ideas, but aims to destabilize real-world hierarchies embedded in the political economy of knowledge production.

\section{Acknowledgements}

Thank you to Pamela Moss and Kathryn Besio for their help with early drafts of this paper, and to the editor and anonymous reviewers at GeoHumanities.

\section{References}

Allen, J. 2004. Homelessness in American literature: Romanticism, realism, and testimony. New York, NY: Routledge.

Askins, K. 2009. "That's just what I do": Placing emotion in academic activism. Emotion, Space and Society 2(1):4-13.

doi:10.1016/j.emospa.2009.03.005.

Behar, R. 1996. The vulnerable observer: Anthropology that breaks your heart. Boston, MA: Beacon Press.

Beverly, J. 1993. Against literature. Minneapolis: University of Minnesota Press.

Blasi, G. 1994. "And we are not seen:” Ideological and political barriers to understanding homelessness. The American Behavioral Scientist 37 (4):56386. doi: $10.1177 / 0002764294037004009$.

Bondi, L. 2005. Making connections and thinking through emotions: Between geography and psychotherapy.

Transactions of the Institute of British Geographers 30 (4):433-48. doi:10.1111/j.1475-5661.2005.00183.

Brozgal, L. N. 2013. Against autobiography: Albert Memmi and the production of theory. Lincoln: University of Nebraska Press.

Buck, P., P. Toro, and M. Ramos. 2004. Media and professional interest in homelessness over 30 years (1974-2003). 
Analyses of Social Issues and Public Policy 4 (1):151-71.

doi: 10.1111/j.15302415.2004.00039.

Butz, D. 2010. Autoethnography as sensibility. In The Sage handbook of qualitative geography, ed. D. DeLyser, S. Herbert, S. Aitken, M. Crang, and L. McDowell, 138-55. Los Angeles, CA: SAGE.

Butz, D., and K. Besio. 2009. Autoethnography. Geography Compass 3 (5):1660-74. doi:10.1111/j.17498198.2009.00279.x.

Byle, A. 2017. Tate Publishing closes its doors. Publishers Weekly. Accessed October 7, 2018. https://www.publishersweekly.com/pw/bytopic/industry-news/religion/article/72590-tate-publishing-closes-itsdoors.html\#comments.

Chaya, E. 2014. Fashion tips for the homeless woman: The unknown homeless woman. Eliana Chaya.

Chaya, E. 2015. The unknown homeless woman. [Facebook post]. Accessed October 7, 2018. https://www.facebook.com/The-Unknown-HomelessWoman-1418619248428321/.

Christensen, J. 2012. Telling stories: Exploring research storytelling as a meaningful approach to knowledge mobilization with Indigenous research collaborators and diverse audiences in community-based participatory research. The Canadian Geographer/Le Géographe Canadien 56 (2):231-42. doi: $10.1111 / \mathrm{j} .15410064 .2012 .00417$.

Cloke, P., P. Milbourne, and R. Widdowfield. 2001. Making the homeless count? Enumerating rough sleepers and the distortion of homelessness. Policy \& Politics 29 (3):259-79. doi:10.1332/0305573012501341.

Collins, P. H. 2002. Black feminist thought: Knowledge, consciousness, and the politics of empowerment. New York, NY: Routledge.

Connell, R. 1997. Why is classical theory classical? American Journal of Sociology 102 (6):1511-57. doi:10.1086/231125.

Connell, R. 2007. Southern theory: The global dynamics of knowledge in social science. Cambridge, MA: Polity. 
Culler, J. 2011. Literary theory: A very short introduction. Oxford, UK: Oxford University Press.

Eighner, L. 1991. Travels with Lizbeth. The Threepenny Review 44:5-9.

Eighner, L. 2013. Travels with Lizbeth: Three years on the road and on the street. New York, NY: St. Martin's Press.

Elliott, J., and D. Attridge. 2011. Introduction: Theory's nine lives. In Theory after theory, ed. J. Elliott and D. Attridge, 1-16. New York, NY: Routledge.

Elwood, S., V. Lawson, and E. Sheppard. 2017. Geographical relational poverty studies. Progress in Human Geography 41 (6):745-65. doi: $10.1177 / 0309132516659706$.

Eshun, G., and C. Madge. 2012. "Now let me share this with you": Exploring poetry as a method for postcolonial geography research. Antipode 44 (4):1395428. doi:10.1111/j.14678330.2011.00968.

Farrugia, D., and J. Gerrard. 2016. Academic knowledge and contemporary poverty: The politics of homelessness research. Sociology 50 (2):267-84. doi: $10.1177 / 0038038514564436$.

Felski, R. 2015. The limits of critique. Chicago, IL: University of Chicago Press.

The Film Archives. 2013. Lee Stringer and Kurt Vonnegut on grand central winter: Stories from the Street (1998) [video file]. Accessed October 7, 2018. https://www.youtube.com/watch?v=2gc8MlHsZRY.

Francis, S., and A. Francis. 2013. Love's all that makes sense: A mother daughter memoir. Dundas, ON: Bridgeross Communications.

Gardner, C. (with Q. Troupe and M. E. Rivas). 2006. The pursuit of happyness. New York, NY: Amistad.

Gilmore, L. 2001. Limit-cases: Trauma, self-representation, and the jurisdictions of identity. Biography 24 (1):128-39. doi:10.1353/bio.2001.0011.

Gordon, A. 2008. Ghostly matters: Haunting and the sociological imagination. Minneapolis: University of Minnesota Press. 
Gorelick, R. 2011. What is theory? Ideas in Ecology and Evolution 4:1-10. doi:10.4033/iee.2011.4.1.c.

Gowan, T. 2010. Hobos, hustlers, and backsliders: Homeless in San Francisco. Minneapolis. MN: University of Minnesota Press.

Gray-Garcia, L. 2006. Criminal of poverty: Growing up homeless in America. San Francisco, CA: City Lights Books.

Halberstam, J. 2011. The queer art of failure. Durham, NC: Duke University Press.

Haraway, D. 1988. Situated knowledges: The science question in feminism and the privilege of partial perspective. Feminist Studies 14 (3):575-99. doi: $10.2307 / 3178066$.

Harding, S. 2016. Whose science? Whose knowledge?: Thinking from women's lives. Ithaca, NY: Cornell University Press.

Hartsock, N. 1983. The feminist standpoint: Developing the ground for a specifically feminist historical materialism. In Discovering reality: Feminist perspectives on epistemology, ed. S. Harding and M. Hintikka, 283-310. Dordrecht, ND: Springer Netherlands.

Hawkins, R., K. Falconer Al-Hindi, P. Moss, and L. Kern. 2016. Practicing collective biography. Geography Compass 10 (4):165-78.

doi: $10.1111 /$ gec 3.12262 .

Hochschild, J. 1996. Facing up to the American dream: Race, class, and the soul of the nation. Princeton, NJ: Princeton University Press.

Hodgetts, D., A. Cullen, and A. Radley. 2005. Television characterizations of homeless people in the United Kingdom. Analyses of Social Issues and Public Policy 5 (1):29-48. doi:10.1111/j.15302415.2005.00054.x.

Hoffmann, J. 2013. The audacity of home: Poor Magazine's new paradigm of place. Bitch Magazine 57. (Accessed October 7, 2018).

https://www.bitchmedia.org/article/the-audacity-of-home-poor-mediamagazine.

Homeless, J. 1992. My life on the street: Memoirs of a faceless man. Far Hills, NJ: New Horizon Press. 
Johnsen, S., J. May, and P. Cloke. 2008. Imag(in)ing 'homeless places': Using auto-photography to (re)examine the geographies of homelessness. Area 40 (2):194-207. doi:10.1111/j.14754762.2008.00801.x.

Klodawsky, F., S. Farrell, and T. D'aubry. 2002. Images of homelessness in Ottawa: Implications for local politics.

The Canadian Geographer/Le Géographe Canadien 46 (2):126-43. doi: $10.1111 / \mathrm{j} .15410064 .2002 . t b 00735 . \mathrm{x}$.

Lancione, M. 2017. The ethnographic novel as activist mode of existence: Translating the field with homeless people and beyond. Social \& Cultural Geography 18 (7):994-1015. doi:10.1080/14649365.2016.1231336.

Lyon-Callo, V. 1999. Review of Out of place: Homeless mobilizations, subcities, and contested landscapes by T. Wright. Rethinking Marxism 11 (3):124-26. doi:10.1080/08935699908685599.

May, J. 2000. Housing histories and homeless careers: A biographical approach. Housing Studies 15 (4):613-38. doi:10.1080/02673030050081131.

Monk, N. 2015. Chasing the mouse: A memoir about childhood homelessness. Nathan Monk.

Moss, P., ed. 2001. Placing autobiography in geography. Syracuse, NY: Syracuse University Press.

Moya, P. 2002. Learning from experience: Minority identities, multicultural struggles. Berkeley: University of California Press.

Nagar, R. 2013. Storytelling and co-authorship in feminist alliance work: Reflections from a journey. Gender, Place \& Culture 20 (1):1-18. doi:10.1080/0966369X.2012.731383.

Nagar, R. 2014. Muddying the waters: Coauthoring feminisms across scholarship and activism. Champaign: University of Illinois Press.

Narayan, K., and K. George. 2002. Personal and folk narrative as cultural representation. In Handbook of interview research, ed. J. Gubrium and J. Holstein, 815-32. Thousand Oaks, CA: Sage Publications. 
Payne, M., and J. Schad. 2003. Life. After. Theory. London, UK: Continuum.

Poitevin, G. 2002. Dalit autobiographical narratives: Figures of subaltern consciousness, assertion and identity. In Biography as religious and cultural text, ed. A. Schule, 77-109. Munster, GER: LIT Verlag.

Purcell, M. 2009. Autobiography. In International encyclopedia of human geography, ed. R. Kitchin and N. Thrift, vol. 1, 234-39. Oxford, UK: Elsevier.

Purser, G. 2016. The circle of dispossession: Evicting the urban poor in Baltimore. Critical Sociology 42 (3):393-415.

doi: $\underline{10.1177 / 0896920514524606 .}$.

Rabbiosi, C., and A. Vanolo. 2017. Are we allowed to use fictional vignettes in cultural geographies? Cultural Geographies 24 (2):265-78.

doi: $10.1177 / 1474474016673064$.

Renedo, A., and S. Jovchelovitch. 2007. Expert knowledge, cognitive polyphasia and health: A study on social representations of homelessness among professionals working in the voluntary sector in London. Journal of Health Psychology 12 (5):779-90. doi:10.1177/1359105307080611.

Riessman, C. 1993. Narrative analysis. Newbury Park, CA: Sage.

Rose, G. 1997. Situating knowledges: Positionality, reflexivities and other tactics. Progress in Human Geography 21(3):305-20.

doi: $10.1191 / 030913297673302122$.

Rossetti, C. 2015. Richard Nash on the democratization of publishing. Publishing Perspectives. Accessed October 7, 2018. https://publishingperspectives.com/2015/05/richard-nash-on-thedemocratization-of-publishing/.

Schmidt, K., and I. M. M. Robaina. 2017. Beyond removal: Critically engaging in research on geographies of homelessness in the city of Rio de Janeiro. Journal of Latin American Geography 16 (1):93-116. doi:10.1353/ lag.2017.0013.

Schneider, B. 2012. Sourcing homelessness: How journalists use sources to frame homelessness. Journalism 13 (1):71-86.

doi: $10.1177 / 1464884911421573$. 
Scott, J. W. 1991. The evidence of experience. Critical Inquiry 17 (4):773-97. doi: $10.1086 / 448612$.

Sedgwick, E. 1997. Paranoid reading and reparative reading, or, you're so paranoid, you probably think this introduction is about you. In Navel gazing: Queer readings in fiction, ed. E. Sedgwick, 1-37. Durham, NC: Duke University Press.

Sibley, J. 2011. Being and homelessness: Notes from an underground artist. Greenwich, CT: Wordsworth Greenwich Press.

Smith, S., and J. Watson. 1998. Women, autobiography, theory: A reader. Madison: University of Wisconsin Press.

Somerville, P. 2013. Understanding homelessness. Housing, Theory and Society 30 (4):384-415. doi:10.1080/ 14036096.2012.756096.

Speer, J. 2018. Losing home: Housing, displacement, and the American Dream. Doctoral dissertation, Syracuse University. https://surface.syr.edu/etd/899.

Stanley, L. 1993. On auto/biography in sociology. Sociology 27 (1):41-52. doi: $10.1177 / 003803859302700105$.

Stanley, L. 1995. The auto/biographical I: The theory and practice of feminist auto/biography. Manchester, UK: Manchester University Press.

Stanley, L. 2012. The knowing because experiencing subject. In Knowing the difference: Feminist perspectives in epistemology, ed. K. Lennon and M. Whitford, 132-48. London, UK: Routledge.

Stone-Mediatore, S. 2016. Reading across borders: Storytelling and knowledges of resistance. New York, NY: Palgrave Macmillan.

Stringer, L. 1998. Grand central winter: Stories from the street. New York, NY: Seven Stories Press.

von Benzon, N., and L. van Blerk, Eds. 2017. Geographical research with vulnerable groups: Reexamining methodological and ethical process [special issue]. Social \& Cultural Geography 18(7).

Walker, A. 2017. Critical autobiography as research. The Qualitative Report 22 (7):1896-908. 
Watson, J., and S. Smith. 2010. Reading autobiography: A guide for interpreting life narratives. Minneapolis: University of Minnesota Press.

Williams, R. 1989. Resources of hope: Culture, democracy, socialism. ed. R. Gable, New York, NY: Verso.

Zeitchik, S. 2004. Authors allege publisher deception. Publishers Weekly 251 (77). 